\title{
A giant myxoma arising from the free wall of the right atria
}

\author{
Nasir Hussain, ${ }^{1,2}$ Atiq Rehman ${ }^{2,3}$
}

1 Department of Cardiology, Hartford Hospital, University of Connecticut, Hartford, Connecticut, USA

${ }^{2}$ College of Physicians and Surgeons of Columbia University, New York, New York, USA

${ }^{3}$ Sarasota Memorial Hospital, Sarasota, Florida, USA

\section{Correspondence to}

Dr Nasir Hussain connect2nasir@gmail.com

Accepted 25 July 2014

\section{CrossMark}

To cite: Hussain N, Rehman A. BMJ Case Rep Published online: [please include Day Month Year] doi:10.1136/bcr-2014206135

\section{DESCRIPTION}

A 67-year-old Caucasian man, an avid golfer with no significant history, presented to the hospital for evaluation of near-syncopal events. The patient had noticed that for the past few months he would be asymptomatic throughout the game, except that with each club swing he would experience a sudden onset of weakness and near-syncopal episodes. The review of symptoms was significant for worsening exertional dyspnoea. His admission vital signs and physical examination were within normal limits. The CT angiogram showed no pulmonary embolism, but a large right atrial mass was noted that was further confirmed by a transoesophageal echocardiogram as shown in figure 1A, B. A cardiac catheterisation demonstrated multivessel coronary artery disease. The patient underwent resection of the right atrial mass with coronary artery bypass grafting; during surgery, the origin of mass from the right atrial free wall was noted; intraoperative images are shown in figure $2 \mathrm{~A}, \mathrm{~B}$. The mass measured $9.0 \times 5.0 \times 3.5 \mathrm{~cm}$, as shown in figure $2 \mathrm{C}$ Histological examination of the mass demonstrated cytologically bland, round to stellate cells
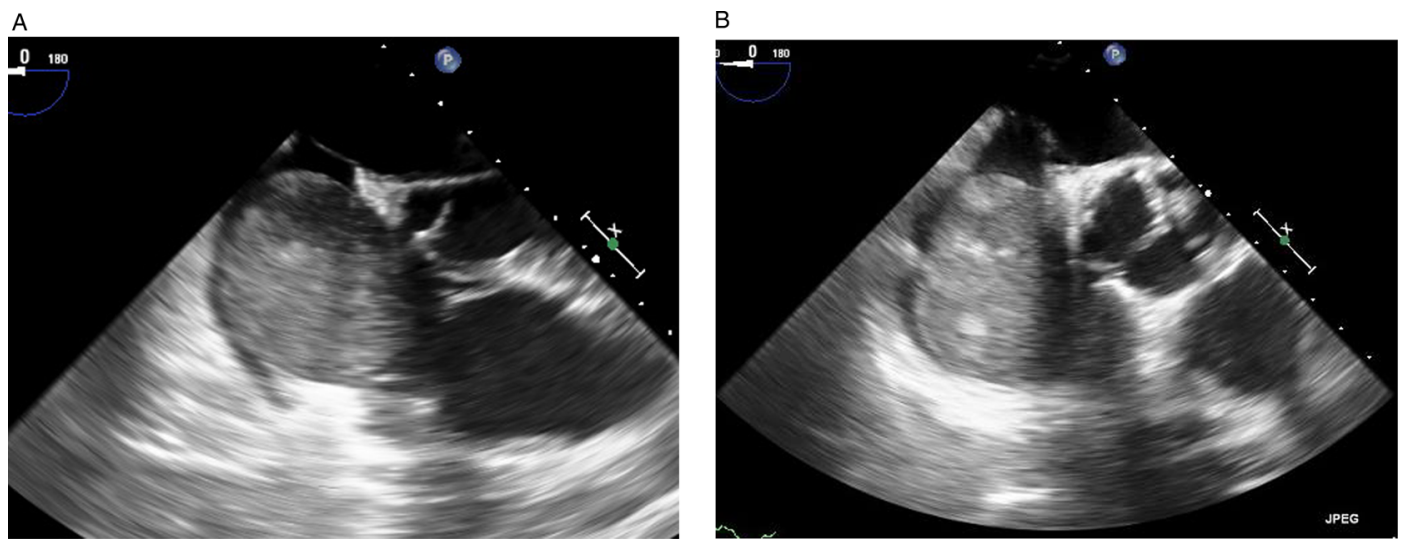

Figure 1 Transoesophageal echocardiographic images. (A) Demonstrating a large mass in the right atrial cavity, the tricuspid valve is at the 4 o'clock position in reference to the mass. (B) Demonstrating the mass nearly obliterating the right atrial cavity. surrounded by loose myxoid stroma, with admixed vascular channels as shown in figure $3 \mathrm{~A}, \mathrm{~B}$; mitoses, pleomorphism and necrosis were absent. The patient had an uneventful postoperative course and was discharged home on day 5. At the 1 month follow-up visit, the patient was recovering well with resolution of prior symptoms.

Myxomas are the most common primary cardiac tumour, and occur commonly between the third and sixth decades with a female predilection. ${ }^{1}$ The right atrial myxomas constitute $15-20 \%$ of all cardiac myxomas, with most arising from the interatrial septum at the border of fossa ovalis and then in descending order of frequency from the posterior wall, anterior wall and atrial appendage. ${ }^{2}$ The myxomas arising from the free wall of the right atria are extremely rare. Cardiac myxomas may present with obstructive, embolic or constitutional symptoms. ${ }^{2} 3$ The tumour size, location, mobility, body position and physical activity affect the nature of obstructive symptoms. ${ }^{3}$ Complete surgical excision is curative with a reduced risk of recurrence and is the only way to establish the definitive diagnosis. ${ }^{2}$ 


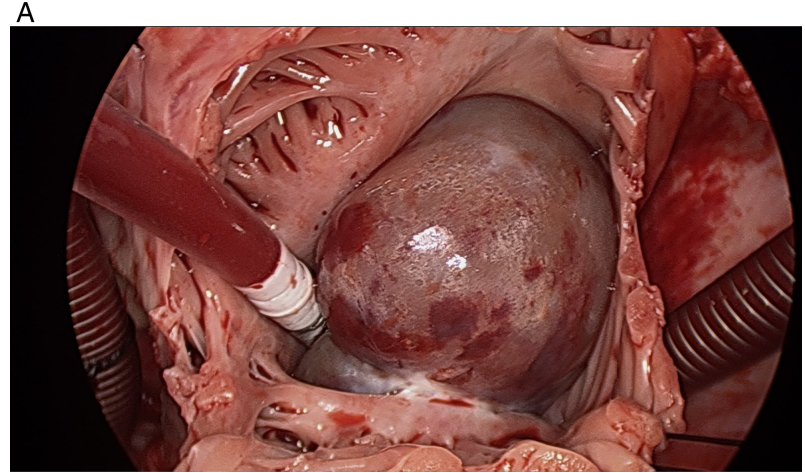

B

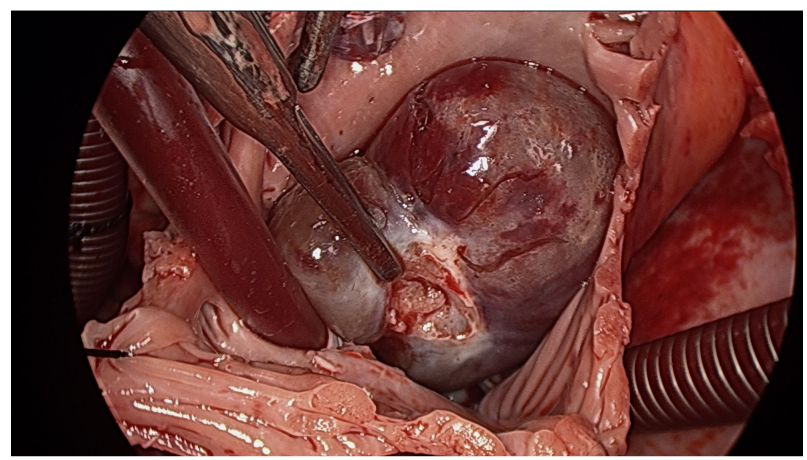

C

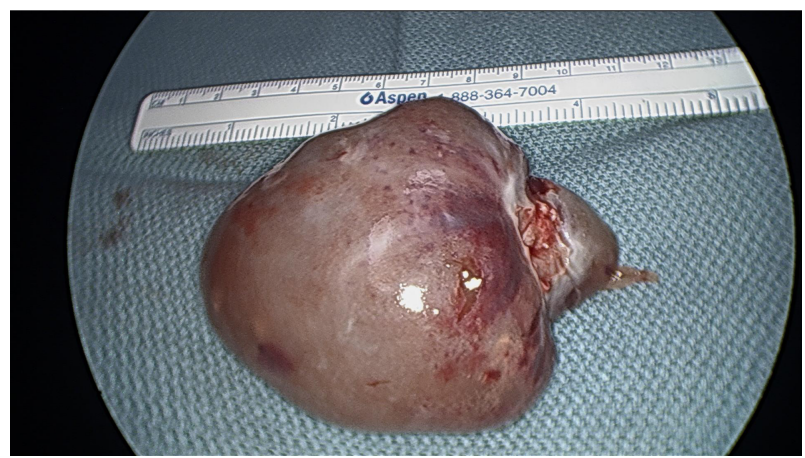

Figure 2 Intraoperative images. (A) Demonstrating a giant mass almost completely obliterating the right atrial cavity, the tricuspid valve is completely covered, with its base attached to the free wall of the right atrium. The cannula at $3 o^{\prime}$ clock is in the inferior vena cava and the one at $9 o^{\prime}$ clock is in the superior vena cava. (B) The mass is detached along with its base/free wall. (C) Demonstrating the gross specimen features of the mass after surgical excision, mass measured $9.0 \times 5.0 \times 3.5 \mathrm{~cm}$.

\section{Learning points}

- Atrial myxomas should be considered in differential diagnosis for right atrial masses.

- Atrial myxomas should be considered in differential diagnosis for exertion-related near-syncope/syncope events.

- Atrial myxomas may grow quite large in size before becoming symptomatic.

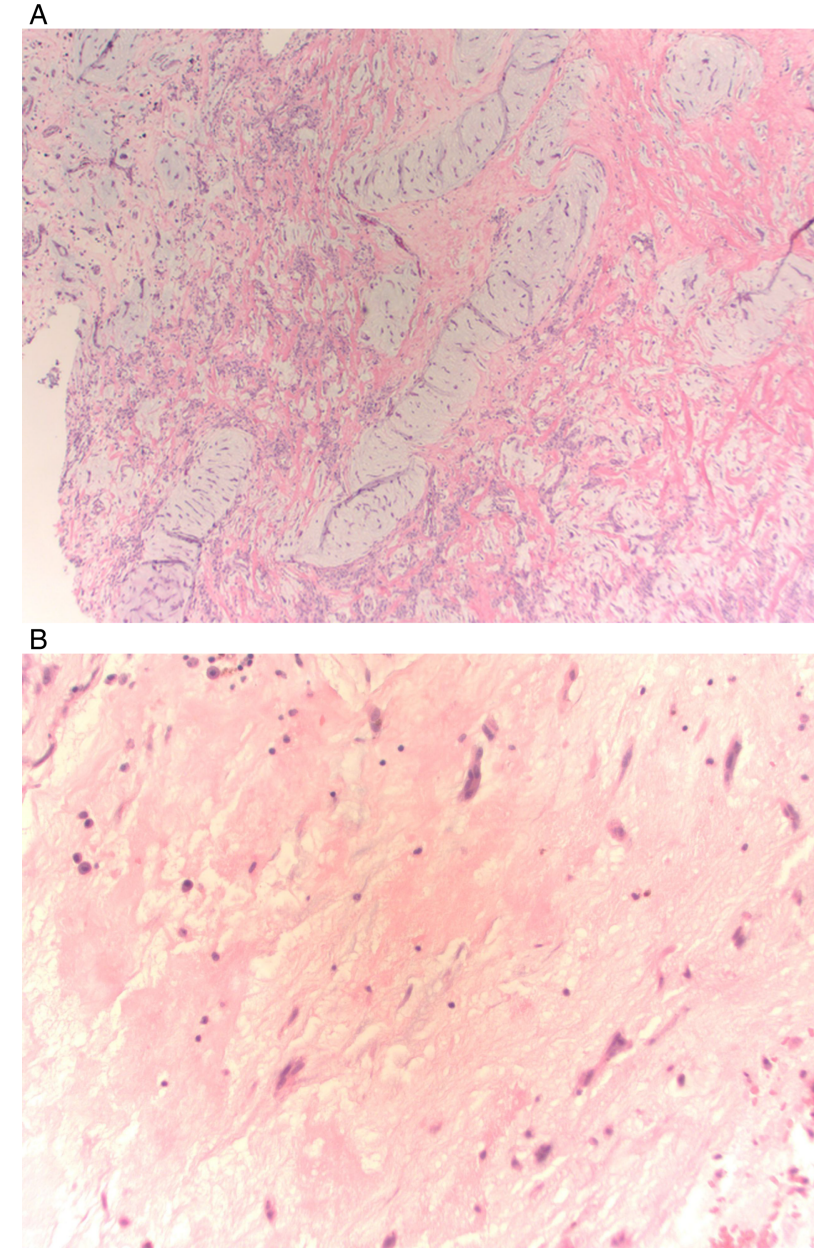

Figure 3 Microscopic images demonstrating cytologically bland, round to stellate cells surrounded by loose myxoid stroma, with admixed vascular channels. (A) Microscopic image at $\times 100$.

(B) Microscopic image at $\times 400$.

Contributors NH was involved in the preparation of the manuscript and literature review. AR was involved in direct patient care and helped with the writing of the manuscript.

Competing interests None.

Patient consent Obtained.

Provenance and peer review Not commissioned; externally peer reviewed.

\section{REFERENCES}

1 Siminelakis S, Kakourou A, Batistatou A, et al. Thirteen years follow-up of heart myxoma operated patients: what is the appropriate surgical technique? I Thorac Dis 2014;6(Suppl 1):S32-8.

2 Reynen K. Cardiac myxomas. N Engl J Med 1995;333:1610-17.

3 Butany J, Nair V, Naseemuddin A, et al. Cardiac tumors: diagnosis and the management. Lancet Oncol 2005;6:219-28. 
Copyright 2014 BMJ Publishing Group. All rights reserved. For permission to reuse any of this content visit http://group.bmj.com/group/rights-licensing/permissions.

BMJ Case Report Fellows may re-use this article for personal use and teaching without any further permission.

Become a Fellow of BMJ Case Reports today and you can:

- Submit as many cases as you like

- Enjoy fast sympathetic peer review and rapid publication of accepted articles

- Access all the published articles

- Re-use any of the published material for personal use and teaching without further permission

For information on Institutional Fellowships contact consortiasales@bmjgroup.com

Visit casereports.bmj.com for more articles like this and to become a Fellow 